\title{
The specificities of criminal women: discussing female invisibility in the literature
} Las especificidades de las mujeres criminales: debatiendo la invisibilidad de las mujeres en la literatura MARIANA BARCINSKI

Pontifícia Universidade Católica do Rio Grande do Sul

\begin{abstract}
The present work aims at discussing the ways in which the literature, especially in Criminology, refers to criminal women. As attested by feminist scholars interested in the topic, female crimes have been theorized from a male standpoint. In other words, no efforts have been constantly made to understand the specificities of crimes perpetrated by women (Daly and Chesney-Lind, 1988: 497-538; Heidensohn, 1993: 309-312). Thus, from both the analysis of the existent literature and data resulting from an empirical study conducted with female drug traffickers in Rio de Janeiro, Brazil (Barcinski, 2008), the goal is to provide elements to further understand the image usually associated to female criminals, as well as the reasons for the invisibility of women in specialized literature.
\end{abstract}

Keywords: female criminality, gender, invisibility, social roles.

\section{Resumen}

El presente trabajo objetiva discutir las maneras por las cuales la literatura, especialmente la de Criminología, se refiere a mujeres criminosas. Como atestan las pensadoras feministas interesadas en el tema, los crímenes femeninos se han teorizado des de un punto de vista masculino. En otras palabras, los esfuerzos para comprender las especificidades de los crímenes perpetrados por mujeres, no han sido constantes (Daly and Chesney-Lind, 1988: 497-538; Heidensohn, 1993: 309-312). Así, desde el análisis de la literatura existente y el análisis de los datos resultantes de un estudio empírico con mujeres traficantes de drogas en Río de Janeiro, Brasil (Barcinski, 2008), el objetivo es aportar elementos para el entendimiento de la imagen usualmente asociada a las mujeres criminales, así como entender las razones de la invisibilidad femenina en la literatura especializada.

Palabras clave: delincuencia femenina, género, invisibilidad, roles sociales.

\section{INTRODUCTION}

From a feminist perspective, the present work has the goal to discuss the ways in which female criminals are portrayed in the literature. The interest in the topic 
emerges from both the lack of attention to female criminality in the literature, and from an empirical study conducted with seven women with a history of involvement in drug trafficking in the slums in Rio de Janeiro, Brazil (Barcinski, 2008). Hence, the arguments that sustain the proposed discussion are based on the existent literature, and on some examples from empirical data, which aim at providing a picture of concrete women who get involved in criminal activities. Although this represents a theoretical piece, the reference to actual data might provide further arguments to understand (and, eventually, to contradict) the ways in which female criminals are portrayed in the literature.

The hegemonic discourses on femininity do not foresee women as criminals or outlaws, which makes the investigation of criminal women's identities particularly interesting. The proposed discussion would draw on gender issues in order to make sense of the almost complete absence on the specificities of female crimes in the literature. Because of the unusual role played by criminal women, their involvement in illicit activities is usually described as the result of subordination to criminal men, or by virtue of their romantic involvement to these men (Steffensmeier; Allan, 1996: 459-487). From the analysis of the literature, the goal is to achieve a deeper understanding of the process through which female criminals are deprived from agency in their decisions to join criminal or illicit activities, being portrayed mainly as victims of criminal men. In contrast, data from the empirical work mentioned above will possibly help assigning agency to women who join criminal activities, removing them from the passive and victimized place usually assigned to them in the literature and in common sense discourses.

\section{Women and Crime}

The exercise of including women in the criminological agenda is still in relative early stages. Within the field of criminology, the absence of research on female offenders is usually accounted for by traditional studies in terms of both women's lower crime rates and the perception that the crimes in which they are involved are minor. Typically, their crimes are not perceived as a social threat or as a problem in which research funds should be invested. As Smart (1976:1) already argued in, «the underdevelopment of this particular area of study seems to be in part a consequence of the pervasiveness of the belief in the relative insignificance of female criminality».

In the literature, the experiences of female offenders are either ignored or analyzed according to a supposed universal culture, class, and history-free feminine nature. Traditional theories restrict the understanding of female criminality to the biological or psychological realms, ignoring the economic, social, and political reali- 
ties of female offenders (Carlen, 1993: 314-316; Gregory, 1993: 316-317; Heidensohn, 1985; Schram and Koons-Witt, 2004: 1-7).

The few accounts that make women visible have attempted to explain the lower rate of female crimes as compared to male crimes. From different perspectives, these theories have addressed the question of why women are so less likely to offend than men. The low incidence of women's crimes has been associated to biological traits, prescriptive social roles, and the assimilation, by both male and female, of a patriarchal ideology (Walker, 2003). Feminist Carol Gilligan (1982) provides a somewhat more positive view, suggesting that women's «ethic of care»-centered on responsiveness in an interconnected network of needs, care, and prevention of harm- makes them less likely to offend.

For the purpose of this present discussion, the ideological reasons for the general invisibility of women in the literature are far more relevant than the statistical reasons typically presented. In her interdisciplinary analysis of the processes through which such invisibility is constructed, for instance, Heidensohn (1993: 313) points to the «ideology of gender» that permeates criminology studies and yields genderstereotyped descriptions of criminality. According to the author, feminist theorists "have tried to show that both the paradigms of deviant behavior and the methods of study of modern sociologists led to the exclusion of women as a central topic". Previous explanations of crime had been explanations of male crime, carried out with no reflection on whether theories, concepts, or results must be gender-specific (Daly and Chesney-Lind, 1988: 497-538).

In an attempt to fill the gap in criminology studies, feminist scholars have been investigating the specificities of women's crimes. It is known, for instance, that when women break the law they do it in circumstances that are very different from those in which men become lawbreakers. Hence, there are questions to be addressed that are specific to women's involvement in criminal activities. In Goodstein's (2001: 3) words «there are some very substantial differences between male and female criminality that virtually scream out for interpretation». Investigating these differences is the first step towards recognizing the role played by gender in prescribing male and female behaviors (including criminal behaviors) in society.

In terms of the specifics of female offenses, Steffensmeier and Allan (1996: 459-487) point to the relational character of women's crimes. The role of men in initiating women into crime, they argue, is a consistent finding across research. Women involved in criminal activities tend to emphasize their role as caretakers, and their involvement in crime is often characterized as protective of personal relationships. Based on interviews conducted with female drug traffickers in slums in Rio de Janeiro, Barcinski (2008) claims that women tended to justify their involvement in drug trafficking by virtue of their relationship with men. In some accounts, men were pointed as motivators for both entering and dropping the drug business. 
Attempts to address the participation of women in criminal activities, which sounded extremely troubling to many feminists, associates the increase in female crimes with women's liberation. Freda Adler (1975), for instance, believed that the arrival of the Second Wave of Feminism during the 1970s coincided with both a dramatic increase in women's criminal activity and the shift of female crime to a more «masculine» kind of law breaking. According to what the author calls the «dark side of liberation», while women have demanded equal opportunities in the fields of legal endeavors, some have also forced their way into the world of major crime such as white-collar crime, murder and robbery. In other words, women's liberation had supposedly given them the right to behave like men, including the right to be violent and crime-prone like them. In arguing that women are closing the gap that separates them from men, Adler (1975: 30) states: «The closer they get, the more alike they look and act».

In a response to Adler's claims, Gregory (1993: 316-317) argues that women who commit crimes can in no sense be regarded as liberated. Male monopoly of social economic power persists despite women's movement seeking equality of opportunities and rights. As much as in the legitimate world of business, women continue to play subordinate roles in organized crime. Within drug trafficking in Brazil, it is common practice to use women, as well as children, to perform either secondary or more dangerous tasks (like transporting drugs from one drop off site to another). The idea is that they raise less suspicion from the police, because it is less expected and socially less acceptable that women and children be involved in criminal activities.

In another response to the 'dark side of liberation' argument, writers highlight the theory's exclusion of factors such as race, ethnicity, and class in the attempt to explain women's involvement in criminal activities. Chapman's (1980) studies, for instance, show the clear connection between labor force participation and female crime, according to which the participation of women in criminal activities increases in periods of economic depression.

However, data attest that the participation in crime might provide women with power and social status that are usually recognized as male prerogatives. The ex drug traffickers interviewed in Barcinski's (2008) studies are extremely proud to have occupied male spaces in the dynamics of drug trafficking, especially when the power achieved is legitimized by criminal men and envied by other women around them. Hence, it does seem that being a criminal woman brings them closer to the male world, where the exercise of power and subjugation are allowed and expected.

Some feminist writers stress the role played by discrimination and poverty in women's crimes (Chesney-Lind, 1989: 5-29; Gilfus, 1992: 5-14). Within a context of patriarchal power relations, victimization and marginalization push women to crime. Rather than being a protective factor, like Adler seems to suggest, inequality functions as a predictor of female crimes. 
In a study with incarcerated women in Hawaii, Chesney-Lind and Rodriguez (1983: 5-29) call attention to the high level of victimization in their life stories. The authors' argument is that victimization at different levels — from abuse and neglect to extreme poverty - results in a process of criminalization unique to women.

The full understanding of female criminality has to involve a broader level of analysis, one that includes an understanding of the control and oppression of women in different spheres, from the family and work to the public space. In Heidensohn's (1993: 314) words: «their [women's] social roles and positions are essential to all explanations of crime, since they depend on assumptions about "masculine" and "feminine" behavior, on the nature of the family and women's role in it and even on variations on the Victorian doctrine of separate spheres for men and women». Along the same lines, Goetting (1988: 3-20) suggests that the lack of attention to violent female offenders might be related to the fact that traditional female role expectations recognize women as victims but not as perpetrators of violence.

This broader level of analysis must include race, class, and ethnicity, since they are, along with gender, interlocking elements in the constitution of women's social positions. As Gregory (1993: 316-317) argues, [...] the ways in which poor, black women are treated within the criminal justice system can only be fully understood in terms of the material and ideological realities of both class and gender. Research shows, for instance, that the majority of women incarcerated in America is young, poor, and from minority groups (American Correctional Association, 1990), a similar scenario found in Brazilian prisons.

Gilfus (1992: 5-14) points to the lack of studies based on a direct appreciation of women's perceptions, experiences, and motivations to join criminal activities. Rather than engaging in understanding the reason for the gender gap in crime rates, the author believes that we need to focus on the experiences of «real» women who engage in crimes.

\section{The Brazilian Case}

In Brazil, female criminality, especially women's involvement in drug trafficking, has been reportedly increasing in the last 15 years. Data show that women's incarceration had increased in 38\% from 2004 and 2008. One alarming fact is that $40 \%$ of these women had been arrested for their involvement in drug trafficking (Centro pela Justiça e pelo Direito Internacional 2007).

In Rio de Janeiro, drug trafficking as an organized activity is mainly concentrated in the favelas. ${ }^{1}$ Because of its specific geographic location and political situation, the favela provides a fertile terrain for the development of the activity.

1 Favela is the specific term to designate the slums in Rio de Janeiro. The term is not translated here because of the strength the expression has. 
The Rio de Janeiro Master Plan, ratified in 1992, defines a favela as «an area, predominantly of housing, characterized by the occupation of land by low-income populations, precarious infrastructure and public services, ${ }^{2}$ narrow and irregular layout of access ways, irregularly shaped and sized plots and unregistered constructions, breaking with legal standards». According to this definition, approximately $20 \%$ of Rio de Janeiro's population currently lives in favelas.

In terms of their social representations, favelas are identified as places marked by a general absence: the absence of basic urban infrastructure, the absence of official and political investments, and the absence of law and order. In summary, the favelas are negatively defined for what they do not have (Souza e Silva, 2004).

Favelas are very different from each other. They differ in terms of the origin of their population (mainly rural immigrants), their sizes, the investment made by governmental and non-profit organizations in the area, their safety, and so forth. However, despite all the differences, favelas are often described in a very homogeneous way. They are perceived as empty spaces waiting to be filled by humanitarian help.

The favelado, the person who lives in a favela, is usually described in opposition to the 'true citizen,' the one living in the cities. It is an interesting opposition that claims the favelas to be separate and independent from the cities. Such an opposition is not solely drawn in terms of spatial locations; it also involves the assessment of people's moral conducts. Accordingly, the term favelado carries a pejorative connotation, signaling a person's inclination to engage in immoral and illicit activities. The dualism has always contributed to locating the favelas and the favelados in the margins. People living in these spaces usually appropriate this dualism in the way they talk; they often call themselves «favelados», «community dwellers», in opposition to people from the «asphalt» (who do not live in favelas). Rather than being a mere linguistic choice, the distinction usually carries an awareness of people's different social locations. Hence, being a favelado means having fewer job opportunities and constantly dealing with the police violence and the society's prejudice.

São Paulo, the largest and richest city of Brazil, is home to the majority of favelas in the country. However, the favelas there are less visible because they are mainly located in poor suburbs, far away from the richest neighborhoods. In contrast, the favelas in Rio de Janeiro are spread throughout the whole city. For this reason, the problems they represent are much more visible to the population in general. It is common to hear that favelas in Rio are 'invading the city,' given the proximity between the hills (where favelas are located) and the «asphalt» (where the middle and upper classes live). Even though favelas had always been perceived as a social problem, the lack of attention and investment from official and governmental agencies is traditionally justified by the fact that favelas are constituted by illegal occupations.

2 Today, most of the favelas in Rio have basic infrastructure, like electricity, gas, and water. 
Drug trafficking made its entrance in the favelas in the 1980s. The absence of official authority, the lack of governmental investment, and the poverty of its population created the perfect scenario for the development of crime and violence. Today, different criminal factions control drug trafficking in the favelas in Rio de Janeiro. Characterized by their highly organized and hierarchical structure, these factions impose their rules to the favelas' population through the use of both extremely violent practices and subtle threats. The factions are so powerful that they limit people's circulation and shape their everyday conduct. For instance, participants in Barcinski's study (2008) tell stories of people who had been violently punished for crossing the artificial lines established by the criminal factions.

Within a criminal faction, drug traffickers have specific roles. As would be the case in a legal company, one can ascend in the business, initially performing subordinate tasks and gradually assuming positions of more responsibility and power. For instance, one can start his/her criminal career as an aviãozinho (a person who does little favors for the drop offs' manager), a vapor (the one who sells the drugs in the drop offs), or a soldado (the one in charge of the manager's safety), and end up being the manager of a drop off (Dowdney, 2003). The most prestigious and profitable tasks, however, are usually performed by men.

\section{Women and Drug Trafficking in Brazil}

Drug trafficking is considered a male activity because men are not only the main users and sellers of drugs, but also the main target of the violence characterizing the activity (Zaluar and Alvito, 1998). Statistical facts point to a major participation of men in the business and in the violence that results from it. In Brazil, 80\% of all violent crimes associated with drug trafficking involve young men, who are both the main victims and perpetrators (Cecchetto, 2004).

The picture described above supports the accounts of traditional criminology, in which women's involvement is either underreported or completely absent. The fact that women's participation in drug trafficking in Brazil has reportedly increased in the last 10 to 5 years has not been sufficient to justify a more extensive interest in the topic.

Ilgenfritz, a criminology professor in Rio de Janeiro, started a research project in 1999 with the objective of drawing a more complete picture of the population of inmates in the state correctional institutions. According to the research, the number of women incarcerated increased by $132 \%$ since 1988, a much higher increase rate than men's incarceration in the same period (Musumeci and Ilgenfritz, 2002).

The analysis of the specific political and economic contexts that have contributed to the increasing number of women in drug trafficking was not the focus of 
Ilgenfritz's project. However, the author calls attention to the necessity to investigate the conditions within which women are allowed in a traditional male activity. It is her belief that any analysis of the potential reasons for female involvement in the activity would be incomplete without an investigation of the structural (political, social, and economic) factors that made possible their entrance and acceptance in this primarily male world.

The few accounts of women directly involved in the business are told as anecdotes; there is a fictional tone surrounding these characters' stories. During studies in poor neighborhoods in Rio de Janeiro, Zaluar (1993: 135-142) mentions only three women involved in criminal activities: Old Dadá, who owned a marijuana drop-off point since the 1960s; Sueli Brazão, who once fought for her men at a knifepoint; and Dona Erinis, who assumed the drug selling in a favela after her son was arrested and convicted. Because of their audacity to perform roles traditionally performed by men, these women became legends in the favelas where they lived: «they were referred to by people from the neighborhoods as special cases, out of ordinary» (Zaluar, 1993: 179).

Despite the increasing number of women involved, the presence of typical patriarchal values in drug trafficking is evident, especially when we investigate the roles often played by the women in it. As Zaluar (1993: 135-142) argues, the activity reproduces the gendered system in different forms. Although drug trafficking is unarguably defined as a subversive activity, the traditional ideology of gender is interestingly mirrored in its internal dynamics.

More than $50 \%$ of the women interviewed in Zaluar's studies refer to their roles as subordinate or secondary. In a similar way, most of the women interviewed in Barcinski's study (2008) had worked as a vapor, the person who sells the drug in the drop offs. Among them, there is one woman who worked as a drop-off's manager. She was very proud of the position she had occupied, primarily because she knew it is not a common accomplishment for women. However, this same woman had to perform subordinate roles in the business (such as cooking, transporting armament, and having sex with the trafficking leaders) in order to 'gain men's confidence', and ascend in the drug business.

Zaluar argues that the presence of traditional and hegemonic values is evident also in the way male criminals in her study refer to the 'ideal woman' and the expectations about her. In the author's words, «an outlaw's true woman is one who helps him in his hour of need, when he is in prison and needs money, a lawyer, clothing, food, and everything else» (Zaluar, 1993: 181). Despite all the suffering, she has to remain on her man's side.

Along the same lines, a character frequently mentioned in the favelas is that of 'the loyal' (a fiel), the official partner of a criminal men. When these men are in prison, the loyal has to remain faithful to him during the time of his sentence. Even 
when men have several lovers outside prison (which is true for most of them), they still have the right to demand their female partners' presence, money, food, and favors to make their lives easier in prison. According to the implicit rules that guide people's behaviors within the drug trafficking dynamics, the loyal has no options; extremely violent punishments are prescribed for women who do not fulfill their obligations when their partners are in such a situation.

The 'woman of gangster'3 is another character that appears in people's account and in the literature. She gets involved in drug trafficking -voluntarily or not- by virtue of her involvement with a gangster. Some of them choose to date a trafficker because of the social and economic status they achieve in the favela, mainly by establishing a distance from other women around them. Others find later that their partners are involved in criminal activities, and the women have virtually no options other than complying with their partners' crimes. The «woman of gangster» and «the loyal» are submitted to the informal rules that guide the relationship of people (especially between men and women) within drug trafficking. In both cases, it is criminal man that provides the central elements to constitute these women's identities; their value is defined basically by the men with whom she establishes close relationships.

Hence, women's participation in drug trafficking - direct or indirectly- is, in many different ways, influenced by their relationship with men. Along with financial difficulties and the lack of opportunities to get a «real» job, emotional involvement with criminal men (partners, husbands, boyfriends, or sons) is mentioned as one of the main reasons for women to get involved in illegal activities (Gay, 2005; Gilfus, 1992: 5-14). For criminal men, in turn, women may represent their last link with morality. They are often described as the only persons capable of convincing men (partners or sons) to give up their lives of crime. In the male criminal's discourse, their romantic connections, and the fear and respect for their mothers, are reasons for them to give up illegal activities.

As the discussion above attests, there is an obvious gap in the literature regarding the specifics of women's participation in criminal activities. Probably because of the obvious influence of men in initiating women in the life of crime, no consistent effort has been made to understand the particular circumstances in which women get involved in illegal activities. Their stories as criminals are either ignored or justified entirely by their emotional involvement with criminal men.

From the experiences of women who had been directly involved in drug trafficking, the following section will attempt to provide some elements to think the specificities of female offenses. The main goal is to subvert traditional explanations of women's crimes, removing them from a victimized and passive position, assigning

3 The term «woman of gangster» («mulher de bandido» in Portuguese) is used in a translated version of Zaluar's 1993 paper. It refers to a woman who gets involved in romantic relationship with gangsters. 
them agency in their decision to join the «criminal world». Because drug trafficking -and crime, in general- continue to be a male activity, the agentive discourses produced by female drug traffickers are still permeated by the acknowledgment of crime and power as male prerogatives. Hence, these discourses are dilemmatic and often contradictory, because they simultaneously affirm female agency as criminals and power and social status as male properties.

\section{Listening to concrete female criminals}

One common way in which participants in Barcinski's study (2008) construct their identities is by establishing the distance between themselves and other women around them. As drug traffickers, they often build this distance by claiming their power as criminals. Being women, participants know that their past experiences in drug trafficking are unconventional, and feel special for having experienced the power and privileges traditionally reserved to men. Moreover, they feel special for being recognized as distinct, particularly when this recognition comes from other women.

The distance to other women is also constructed by claiming them to had been distinct criminals. Thus, as criminals, participants often compare themselves to other women involved in drug trafficking. Not surprisingly, they usually claim themselves to be stronger, more courageous, and more respected than other female gangsters.

Hence, the examples below show how these participants construct their identities mainly in comparison to women around them, both by emphasizing the uniqueness of their involvement in drug trafficking, and their uniqueness as criminals. In other words, it is by alignment themselves to men and to male activities that participants in Barcinski's study define themselves as special women. They mention the respect they used to get as criminals; they felt powerful when carrying guns, entering in combat with the police or rival factions and being feared by people.

\section{Being a (different) female gangster ${ }^{4}$}

Vanessa, for instance, is proud of having been «one of the guys»; as a gangster, she was always around men, taking part in the risky tasks that are typically not performed by women. She feels above other women, mainly because she ascended in an activity that is controlled by men. Denise, in accounts that sound somewhat unrealistic, mentions the several employees she had when she was a drop offs manager. She openly claims that she was superior to other women because she had

4 The names of participants are all pseudonyms. 
done crazy things as a trafficker. As pointed out in the analysis of her interviews, the crazy things were usually risky tasks commonly assigned to women or children because of their lower visibility as criminals.

Selma, who claims to having been one of the few women involved in drug trafficking in the 80s, vehemently denies any external influences in her decision to join the activity. For her, it was her attraction to guns and the power associated with being in the position of a female gangster that led her to criminal activities.

When focusing solely on the dominant discourses regarding gender roles and expectations, it is surprising to hear most of the participants claiming to feel powerful when carrying guns and being feared by people. According to a number of feminist writers (e.g., Gilligan, 1982; Miller, 1986), women usually experience power through the connections they are able to establish with people in their lives.

The ways participants characterize their power in drug trafficking reflects the conflict between being a woman and experiencing power in such a masculine way. Selma is the participant who most clearly expresses the restrictions to women's power in criminal activities; as a woman, she experienced power within constraints. In an explicit acknowledgment of men's dominant positions, she claims to be proud for having had a certain power in drug trafficking.

Rather than experiencing power in absolute terms, participants feel powerful almost exclusively when comparing themselves to other women. Selma, Denise, and Vanessa were different from other female gangsters who, according to their descriptions, would be 'just selling drugs in the drop-offs' (a task considered minor and risk-free according to them).

Hence, as women participants exert their constrained power mainly over other women, whom they perceive as weak and vulnerable in some way. In a context where power is clearly defined as a male possession, these women align themselves with men not only by performing typical male activities but also by submitting other women to their power.

\section{Other women being used in drug trafficking}

In the interviews, participants are asked about the differences between the roles played by men and women in drug trafficking. Although they do not necessarily show a critical perspective on the issue, they all mention women being exploited by men in the activity. When commenting on the increasing number of women in drug trafficking, most participants cite the fact that female traffickers raise less suspicion from the police. For this reason, they are assigned risky tasks, such as transporting drugs and guns among favelas and taking forbidden things (e.g., cell phones and money) for their incarcerated partners. 
Most of the participants, however, do not perceive the roles they played in drug trafficking as subordinate. Denise, for instance, used to cook for the gang mates and to have sex with the gangs' leaders. While she started her career as a gangster assisting men in some of their basic needs, cooking and having sex with them are described by Denise as natural steps in her ascendance as a gangster. Commenting on the traditional role of women in serving others (men and children), Miller (1986: 61) argues that "[...] «women» have developed the sense that their lives should be guided by the constant need to attune themselves to the wishes, desires, and needs of others." Drawing from a similar discourse, Denise does not problematize the roles she initially performed in drug trafficking, probably because they were naturally suited to women in that context.

Flávia is one of the few participants who do present a consistent critical analysis of women's participation in drug trafficking. She openly discusses how women are used and exploited in the business. As the analysis of her interviews shows, however, she does not assume the same critical position in relation to her own participation. Even though she describes the many times when her presence among her male gang mates was used to disguise illegal activities (like selling drugs or performing robberies), Flávia sees her participation in drug trafficking in a different way. For her, exploitation and oppression against women in drug trafficking are not part of her own experience as a drug trafficker. Because she used to date the gang's leader, she had privileges that other women involved did not have. Interestingly, even though she had a romantic relationship with a (powerful) trafficker, Flávia never refer to herself as a «woman of gangster». Once again, the label and the realities involved in being a woman in drug trafficking do not apply to her own situation.

Hence, on the rare occasions when participants problematize typical female and male roles in drug trafficking, their general appreciation of women's involvement in the activity sounds disconnected from their own experiences as traffickers. The exploitation is perceived as such only when referred to other female traffickers. It is by distancing themselves from the mistreatment suffered by other women in drug trafficking that participants establish their uniqueness as female traffickers.

\section{Being a different 'woman of gangster'}

Participants often refer to the status of being a 'woman of gangster'; some of them were/are women of gangsters themselves. Their accounts oscillate between supporting and critiquing the position of women who get involved with criminal men. While they understand the status and privileges associated with being in this position, they often portray these women as stupid, submissive, and opportunistic. Because of their ambiguous evaluation, participants provide conflicting accounts marked simul- 
taneously by subtle empathy and overt criticism. What is relevant is that the criticism about other women does not apply to themselves as 'women of gangsters.'

Flávia critiques women who get involved with gangsters. Surprisingly, her critique is not based on the questionable conduct or character of criminal men but rather on these women's desire to take advantage of them. They are described as women who do not want to work and who are just interested in enjoying the status of being a «woman of gangster». Once again, it is striking that she does not extend the critical perspective to her own behavior. Although she enjoyed the benefits of being a «woman of gangster», such as having money and drugs to spare, Flávia does not place herself among the women she critiques. On one of the rare occasions in which she acknowledges her role as a «woman of gangster», she says with pride that her gangster lover had always trusted her above his own wife.

Sandra provides an extremely unsympathetic judgment of the nine girlfriends (five of them pregnant) her criminal son left when he died. According to her, they were only interested in the «good life» her son was able to give them. In an attempt to distance herself from these other 'women of gangster,' Sandra claims many times during her interviews that she did not know about her husband's criminal activities when they got married. Hence, she establishes the difference between herself (who had accidentally been transformed into a «woman of gangster») and other women who consciously decide to get involved with gangsters. Even though she also enjoyed the «good life» her criminal husband provided to her and their children, Sandra never chose to be a 'woman of gangster». This difference in their trajectories is enough to evidence the (moral) distance that separates Sandra and her son's girlfriends.

\section{Conclusion}

Distancing themselves from other women in the ways described above seems to serve different functions in the process of criminal woman identity's construction. First, as exdrug traffickers (reformed criminals), these women seem particularly invested in following the social expectations regarding female roles. As «ideal women», they distance themselves from women who are/were engaged in 'bad behaviors.' Like the women they critique, Flávia and Sandra were also «women of gangsters». Thus, in order to tell a coherent story about themselves as «ideal women», they attempt to legitimize their past conduct. While the involvement of other women with criminal men is presented simply as examples of inappropriate female behavior, their own stories are told in a more nuanced and contextualized way.

Second, and more important for the purpose of this present work, being different from other women remove criminal women - even if temporarily- from 
the invisibility that characterize women's lives, both in the violent peripheries and in the statistics on criminality. While the accounts of concrete women involved in crimes do attest do their subordinate role in relation to men, and to the relational aspect of their crimes, affirming themselves to be agentive in their decisions to join drug trafficking, as well as affirming their braveness to engage in typical male tasks, legitimate these women's uniqueness. From a gender perspective, in a male territory, where women are constantly and in many ways subjugated to the power of men, being a gangster means the possibility to exert a type of power socially legitimized only by men.

While the discussion conducted in this piece means the attempt to remove women from a victimized position in regards to their engagement in crimes, the concrete examples brought to investigation do corroborate women's secondary roles as criminals. Even when considering that female gangster can agentively exert power and violence, it is intriguing that these are usually exerted over women perceived as weaker and more vulnerable. In other words, as the discussion attests, the power that represents being a criminal person, and being able to experiment the status and privileges associated to this role, are still male prerogatives. When quoting one participant's statement: women are allowed to exert only «a certain power».

\section{References}

AdLer, F. (1975): Sisters in crime, McGraw Hill, New York.

AMERICAN CORRECTIONAL ASSOCIATION (1990): The female offender: What does the future hold? American Correctional Association, Laurel, MD.

Carlen, P. (1993): «Women, crime, feminism and realism.» In S. Jackson et al. (Eds.) (1993): Women's studies: Essential readings, New York University Press, New York.

Cecchetto, F. (2004): Violência e estilos de masculinidade, FGV, Río de Janeiro.

Centro pela Justiça e pelo Direito Internacional (2007): Relatório sobre mulheres encarceradas no Brasil

Chapman, J. (1980): Economic realities and the female offender, Lexington Books, Lexington.

Chesney-Lind, M. (1989): "Girls' crimes and woman's place: Towards a feminist model of female delinquency», Crime and Delinquency, 35.

Chesney-Lind, M., and Rodriguez, N. (1983): «Women under lock and key: A view from the inside», The Prison Journal, 63.

DALY, K., and ChesNeY-LIND, M. (1988): «Feminism and criminology», Justice Quarterly, 5. Dowdney, L. (2003): Crianças no tráfico: Um estudo de caso de crianças em violênica armada organizada no Rio de Janeiro, 7 Letras, Río de Janeiro. 
GAY, R. (2005): Lucia: Testimonies of a Brazilian drug dealer's woman, Temple University Press, Philadelphia.

GiLfus, M. (1992): «From victims to survivors to offenders: Women's routes of entry and immersion into street crime». In L. F. ALARID and P. CROMWELL (Eds.) (1992): In her own words: Women offenders' views on crime and victimization, Roxbury Publishing Company, Los Angeles.

Gilligan, C. (1982): In a different voice: Psychological theory and women's development, Harvard University Press, Cambridge.

Goetting, A. (1988): «Patterns of homicide among women», Journal of Interpersonal Violence, 3 .

Goodstein, L. (2001): «Women, crime, and criminal justice: An overview» In C. M. RENZETTI AND L. GOODSTEIN (Eds.) (2001): Women, crime, and criminal justice: Original feminist readings, Roxbury Publishing Company, Los Angeles.

Gregory, J. (1993): «Sex, class and crime». In s. JACKSON and others (Eds.) (1993): Women's studies: Essential readings, New York University Press, New York.

Heidensohn, F. (1985): Women and crime, New York University Press, New York.

-(1993): «Crime and society». Ins. JACKSON and others (Eds.) (1993): Women's studies: Essential readings, New York University Press, New York.

Miller, J. B. (1986): Towards a new psychology of womem, Beacon Press, Boston.

Musumeci, B. and Ilgenfritz, I. (2002): Prisioneiras: Vida e violência atrás das grades, Garamond, Río de Janeiro.

SMART, C. (1976): Women, crime, and criminology: A feminist critique, Routledge \& Kegan Paul, London.

Steffensmeier, D. and allan, E. (1996): «Gender and crime: Toward a gendered theory of female offending», Annual Review of Sociology, 22.

Schram, P. J. and Koons-WITT, B. (2004): "Feminist theory and criminology" In Gendered (In)justice: Theory and practice in feminist criminology (pp. 1-7). Waveland Press, Long Grove.

SouzA and Silva, J. (2004): «Considerações sobre incluidos e excluidos sociais: Crianças e adolescentes no tráfico de drogas», In Direitos Humanos no Brasil. Relatório da Rede Social de Justiça e Direitos Humanos.

Walker, G. (2003): Crime, gender and social order in early modern England, Cambridge University Press, Cambridge.

Zaluar, A. (1993): «Women of gangsters: Chronicle of a less-than-musical city» Estudos Feministas, 1.

Zaluar, A. and Alvito, M. (1998): Um século de favela, FGV, Río de Janeiro. 